\title{
Journal of Production Engineering
}

JPE (2017) Vol.20 (2)

Busari, Y.O., Ahmed, I.I., Shuaib-Babata, Y.L.

Original Scientific Paper

\section{EFFECT OF HEAT INPUT ON THE MECHANICAL AND CORROSION BEHAVIOUR OF SMAW MILD STEEL}

Received: 13 October 2017 / Accepted: 29 November 2017

\begin{abstract}
This study was carried out to assess the effect of heat input on the mechanical properties and corrosion behaviour of mild steel. The intrinsic nature of fusion welding has made it difficult to provide a complete understanding of corrosion behaviour in some systems. Optical metallography was used to determine grain size and $H A Z$ zone, weldment and parent metal. Mechanical properties of the weldment were observed. Corrosion behaviour of mild steel were investigated in air, sea water, alkaline and acidic medium after welding with shielded metal Arc welding SMAW by varying the welding process parameter that leads to power input and monitoring its welding speed with a stop watch. The microstructural characterization of the welded sample carried out through a metallurgical microscope $(x 100)$ and the corrosion response rate by weight loss was observed in the different medium, the sample welded with $180 \mathrm{~A}$ and low voltage displayed the highest Rockwell hardness and the same was observed for impact test. The effect of various heat inputs on the corrosion behaviour of shielded metal arc welded mild steel show thus the as-received sample have the greatest resistance to corrosion in all the medium, at 180 A, high voltage this is closely followed by sample welded with $180 \mathrm{~A}$, low voltage. The sample welded with $90 \mathrm{~A}$, low voltage which has the least corrosion resistance in all medium during the exposure period studied. The low heat input welded samples underwent a long period of heating, low heat input could lead to a greater tendency of distortion which may produce a higher weld cracking in the aggressive corrosion medium. The higher the current, the higher the power input and the deeper the penetration. However, the use of too high weld current may cause problems such as excessive spatter, electrode overheating and cracking while too high weld voltage could cause the beads to be wider and flatter. The low arc voltage produces a stiffer arc that improves penetration. If the voltage is too low, a very narrow bead will result.
\end{abstract}

Key words: Heat input, corrosion resistance, weldment, low voltage, high voltage

Uticaj zagrevanja na mehaničko i korozijsko ponašanje mekog čelika. Ova studija je sprovedena radi procene uticaja toplotne energije na mehaničke osobine i korozivno ponašanje mekog čelika. Unutrašnja priroda fuzionog zavarivanja otežavala je pružanje potpunog razumevanja korozionog ponašanja u nekim sistemima. Optička metalografija je korišćena za određivanje veličine zrna i HAZ zone, zavarivanja i matičnog metala. Praćene su mehaničke osobine zavarivanja. Korozivno ponašanje mekog čelika ispitano je u vazduhu, morskoj vodi, alkalnom $i$ kiselom medijumu nakon zavarivanja sa zaštićenim metalom Arc varenje SMAV promenljivim parametrom procesa zavarivanja koji dovodi do ulaska snage i praćenja brzine zavarivanja sa štopericom. Mikrostrukturna karakterizacija zavarenog uzorka izvedenog kroz metalurški mikroskop (x100) i stepen korozionog odziva gubitka težine zabeležen je u različitom medijumu, uzorak zavaren sa 180 A i nizak napon dao je najvišu tvrdoću Rockvell-a i isto je primé́eno za udarni test. Efekat različitih toplotnih ulaza na korozivno ponašanje zaštićenog mekog čelika zavarenog pomoću luka pokazuje da primljeni uzorak ima najveću otpornost na koroziju u svim sredstvima, na 180 A, visokom naponu, ovo prati i uzorak zavaren sa 180 A, niski napon. Uzorak zavaren sa 90A, niskog napona ima najmanju otpornost na koroziju u svim sredinama tokom istraženog perioda izlaganja. Uzorci zavarenih pri niskim toplotama prošli su dug period zagrijavanja, mala ulazna toplota može dovesti do veće tendencije distorzije, što može dovesti do većeh pukotina vara u agresivnom korozionom medijumu. Što je veća struja, to je veća snaga $i$ dublji prodor. Međutim, korišćenje prevelike struje zavarivanja može izazvati probleme kao što su prekomerno prskanje, pregrijavanje elektroda i pucanje, dok previsok napon zavarivanja može prouzrokovati širi i ravan zavar. Nizak lučni napon stvara čvršći luk koji poboljšava penetraciju. Ako je napon prenizak, rezultiraće vrlo usko.

Ključne reči: Zagrevanje, otpornost na koroziju, zavarivanje, niski napon, visoki napon

\section{INTRODUCTION}

The importance of mild steel in industrial applications and its development cannot be overemphasised. Mild steel is the most commonly used steel on account of relatively low and good material and mechanical properties that are suitable for many applications particularly in severe condition such as extreme weather, greenhouse effect, external massive loads and corrosive marine environment. Therefore the material characteristic such as corrosion behaviour under above condition is required.

The weldment of structural steel corrodes due to exposure to moisture in the air, but the process can be strongly influenced by the presence of certain components and change in its microstructure. Corrosion can be localised to form pits, or it can extend across a wide area to produce general 
deterioration [1].

Corrosion controlled treatments such as passivation and chromate-conversion may be engineered to enhance material's corrosion resistance. When metal atoms are exposed to an environment containing water molecules, electrons are released from the atoms to become positively charged ions, provided a closed electrical circuit can be established. This phenomena lead to localized corrosion in form of a pit. Pit is often developed when the exist localised anodic cell that is much smaller than cathodic cell. Usually common highly corrosion resistance alloy in contact aggressive electrolyte such as chloride. In extreme case, pit can develop to crack initiation point, which propagates and eventually results to failure such may be found in fatigue failure and stress corrosion cracking [2]. Pitting corrosion may also occur in areas where microstructural changes have occurred due to welding operations [3].

Fusion welding is a common technique for joining structural materials which are predisposed to corrosive environments such as sea water, chemicals in reactors couple with dynamic loading arising from pressure changes and thermal shocks due to start-up and shut down shocks [4].

Corrosion response of welded mild steel embedded in coastal soil environment is higher than the dry land area. This study further carried out the comparative study showing that, thus the corrosion rate is lower in plain mild steel than the welded mild steel in the coastal environment [5].

\section{MATERIALS AND EXPERIMENTAL PROCEDURES}

A flat bar of mild steel was used for the experiment and its composition is presented in table below.

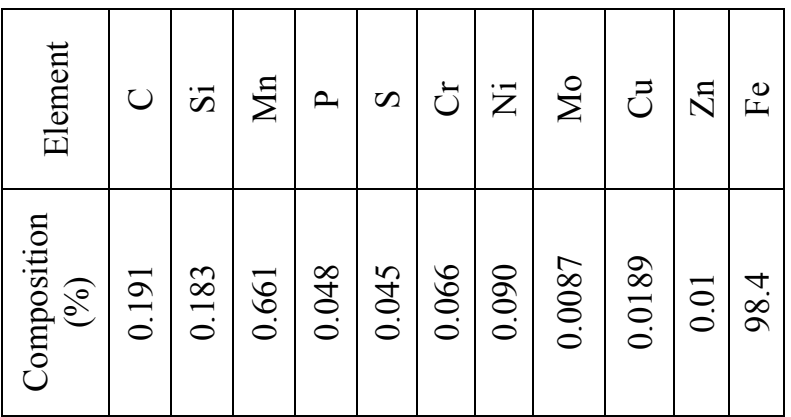

Table 1. Chemical composition of the material used

The edges of these samples were firmly clamped together with a little gap between them to reduce the warping of the welded joint after welding. Low hydrogen electrode gauge $3.25 \mathrm{~mm}$ was used for all the welding operation (AWS E7018-1) because of its moisture resistance electrode.

The welding was carried out using shielded metal arc welding (SMAW). The voltage was varied between low voltage and high voltage using the arc length to determine these [6].

Sample were welded to produce five samples for one condition then after current and arc voltage was varied and the constant welding speed was monitored with aid of a stop watch.
The changes in mechanical property of weldment due to welding parameters used can be related to the changes in the microstructures of weld zone. According to following function, the change in fusion/arc welding parameters results in the variations in welding heat input [7]:

$$
H=\frac{(60 E I)}{(1000 S)}
$$

Where:

$$
\begin{aligned}
& \mathrm{H}=\text { heat input }(\mathrm{kJ} / \mathrm{mm}), \\
& \mathrm{E}=\text { Arc voltage }(\mathrm{V}), \\
& \mathrm{I}=\text { welding current }(\mathrm{A}), \\
& \mathrm{S}=\text { welding speed }(\mathrm{mm} / \mathrm{min})
\end{aligned}
$$

Varying the heat input typically affect the mechanical properties and microstructure of weld. The amount of heat input influences cooling rate [8].

The six samples were welded in pairs when the current and voltage was varied to give different heat input, and the welding time was observed as much as possible. The current settings used were 180A, $135 \mathrm{~A}$ and $90 \mathrm{~A}$, the voltage used was assumed to be $20 \mathrm{~V}$ at low voltage and $30 \mathrm{~V}$ at high voltage. The range of current used is in accordance with the American Welding Society codes (AWS). During welding, the electrode was run through the gap of the weld piece until the penetration and development of the weld pool were achieved to the thickness level of the bar.

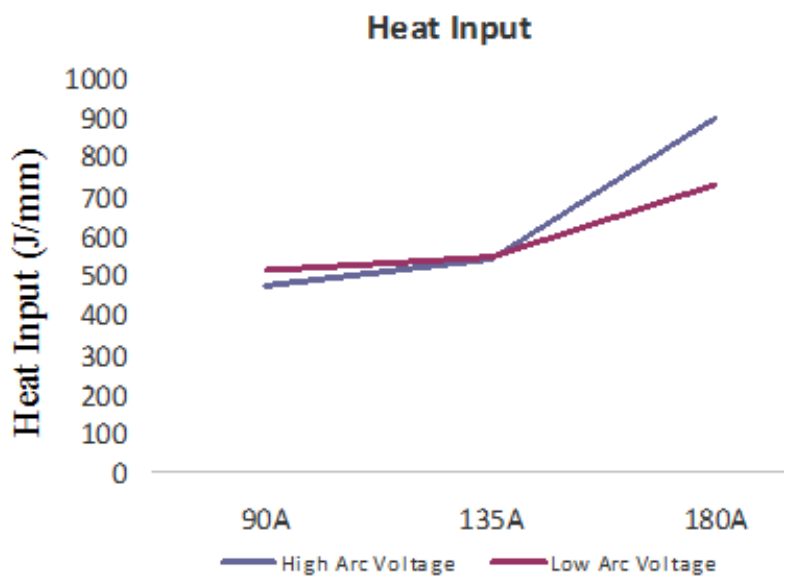

Fig. 1. graphical representation of heat input

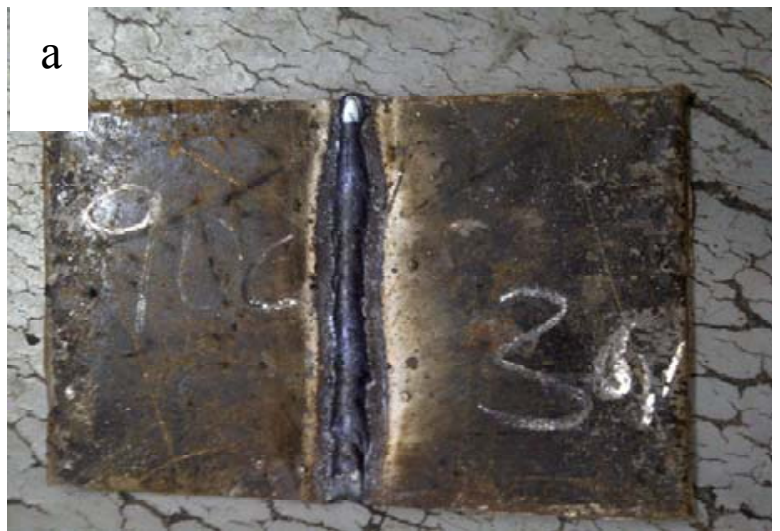



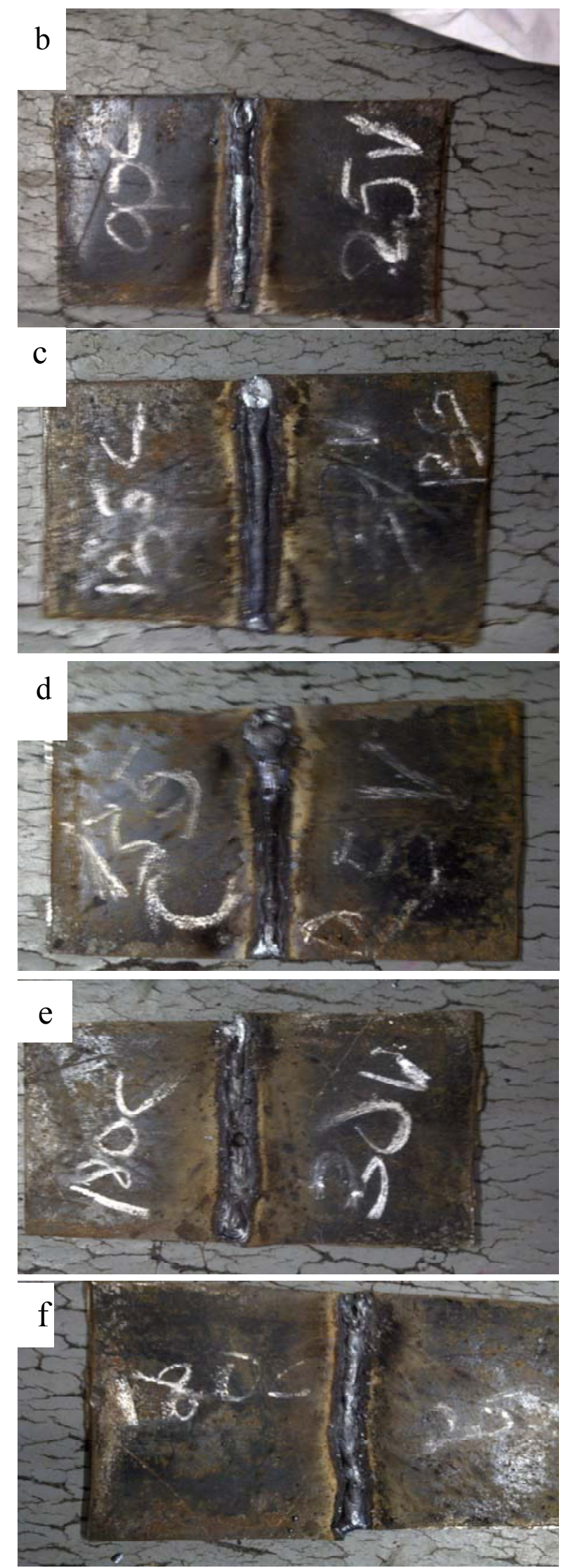

Fig. 2. Weld sample at (a). 90A, High Voltage (b). 90A, Low Voltage (c). 135A,High Voltage (d). 135A, Low Voltage (e). 180A, High Voltage (f). 180A. Low Voltage

The welded samples were cut with hack saw and then machined into shape for microstructural examination, mechanical and corrosion test. It was ensured that the welded portion was captured in the middle of the gauge length. Sample of sea water was obtained from Bar Beach, $1 \mathrm{M} \mathrm{NaOH}$ (sodium hydroxide) and $0.5 \mathrm{M}$ of $\mathrm{HCl}$ was prepared in the laboratory.

\section{MICROSTRUCTURAL EXAMINATION}

The welded samples were first rough ground on a bench vice using a grinder. The samples were later taken for smooth grinding by making use of 220 emery papers. The smoothened surface of these samples was polished in other to remove scratches obtained during the grinding process. Samples were held on the polishing machine containing moist aluminium powder. The samples were then etched at room temperature for about 2 minutes in a V2A etchant solution made of $100 \mathrm{ml}$ hydrochloric acid, 10 $\mathrm{ml}$ of ethanol, both of which were dissolved in $100 \mathrm{ml}$ of water. The etched samples were finally examined under a metallurgical microscope at a magnification of X100 micron. The steps followed for this metallographic preparation is as spelt out by Zipperian [9].

\section{CORROSION}

The specimens were immersed in the various prepared media separately; each specimen is then brought out on weekly basis; cleaned, dried and weighed to obtain the weight loss. This is then used to calculate CORROSION PENETRATION RATE (CPR) from the expression:

$$
\mathrm{CPR}=\mathrm{kw} / \mathrm{\rho At} \quad(\mathrm{mm} / \mathrm{yr} .)
$$

Where:

$$
\begin{aligned}
& \mathrm{CPR}=\text { corrosion penetration rate }(\mathrm{mm} / \mathrm{yr} \text {. }) \\
& \mathrm{k}=\text { a constant of value }=3.16 \times 10^{8} \\
& \mathrm{w}=\text { weight loss due to corrosion }(\mathrm{mg}) \\
& \mathrm{t}=\text { exposure time }(\mathrm{sec}) \\
& \rho=\text { density in } \mathrm{g} / \mathrm{mm}^{3} \\
& \mathrm{~A}=\text { specimen surface area }\left(\mathrm{mm}^{2}\right)
\end{aligned}
$$

After the preparation of the various corrosive medium, the plastic cup was properly labelled, the samples was tied to a wool thread and the required measured quantity of sea water, $\mathrm{NaOH}$ and $\mathrm{HCl}$ was placed in the cups, then the samples were placed in the prepared corrosive medium, for the $\mathrm{HCl}$ the weight loss was measured in the intervals of two (5) days while that of sea water and $\mathrm{NaOH}$ was observed at 10 days interval.

\section{RESULTS AND DISCUSSION}

\subsection{Microstructural observation}

The microstructures of the weldment were characterized by pseudo-grains and the microstructure are not uniform throughout in composition which is as a result of faster cooling rates. Most of the zone contains ferrite and some pearlites which accout for the relative hardness.

The figure 3(b), (d) and (f) microstructure that 
evolved in the weldment are heterogeneous due to the temperature gradient that results from high voltage and the welding process parameter evolves the chemical gradient. Also, the heat affected zone that is between the weldment and base metal contains larger grains.
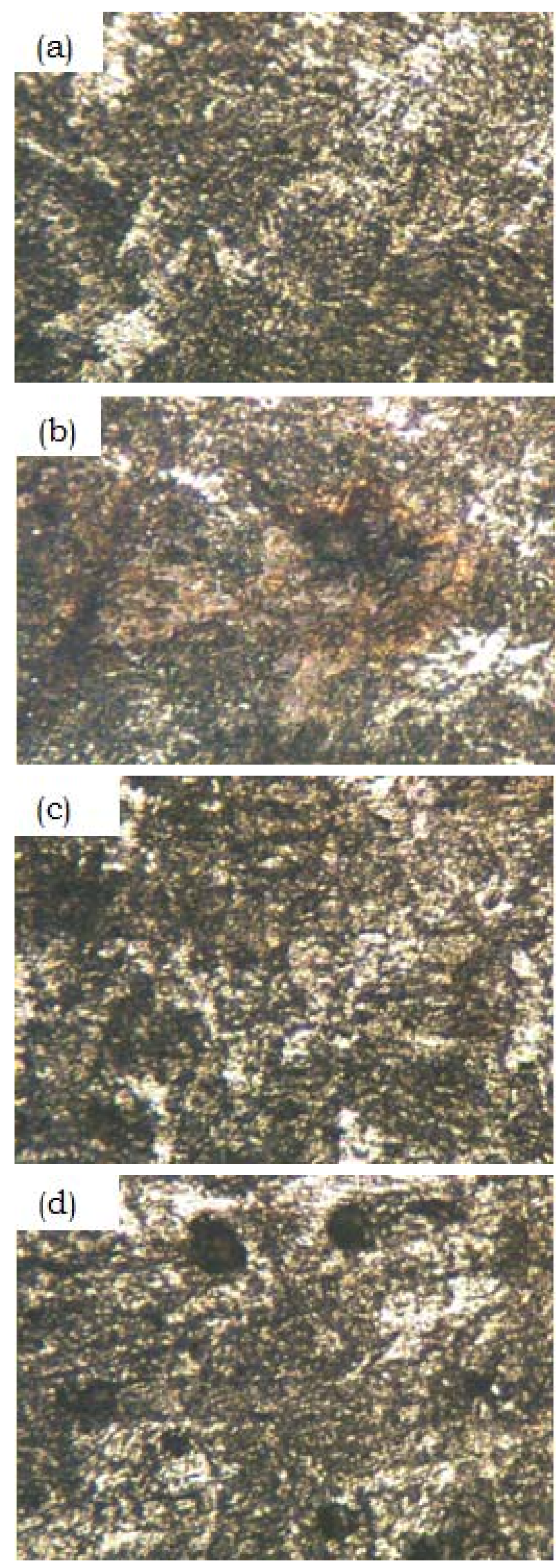
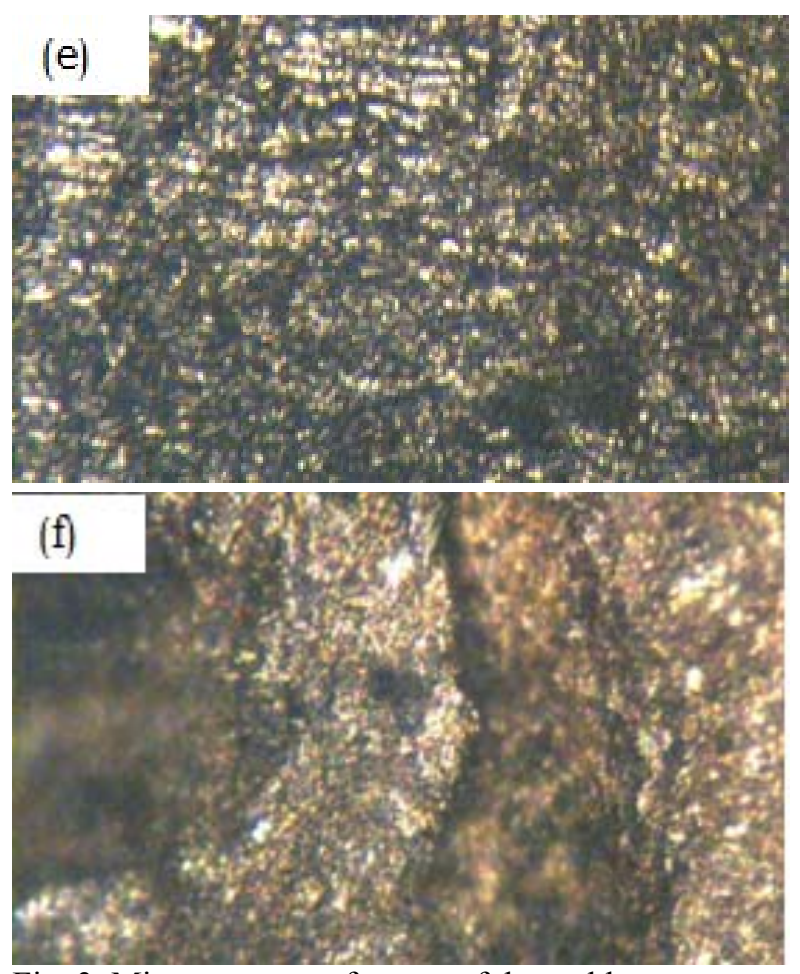

Fig. 3. Microstructure of centre of the weldment produced with different heat input; (a). 90A, Low Voltage, (b). 90A, high Voltage (c). 135A, Low Voltage (d). 135A, High Voltage (e). 180A, Low Voltage (f). 180A, high Voltage (x100)

\subsection{Mechanical properties}

The Rockwell hardness of the heat affected zone is higher than the various heat input welded samples as represented graphically below. The sample welded with $180 \mathrm{~A}$ and low voltage displayed the highest Rockwell hardness among the welded sample, There is not much change in hardness of the material observed by increasing the rate of heat input. Although the amount of the heat input increases the size of the heat affected zone, but the value of the hardness remains within a certain range. We have observed that bands of coarse grains grow along a certain preferred crystallographic directions. Moreover, we have found that maximum hardness values are situated in the area of weld metal and HAZ which indicates its specificity. This may be due to the fact that the martenstic transformation.

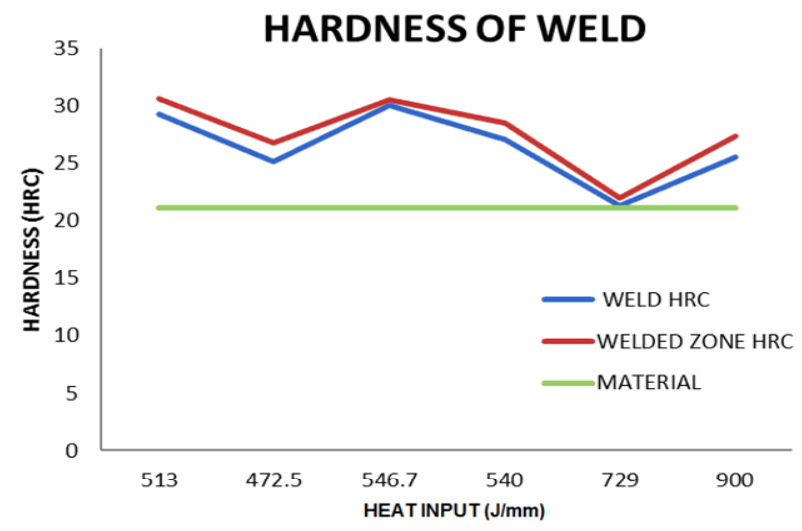

Fig. 4. Graphical representation of hardness of parent metal, weldment and heat affected zone 


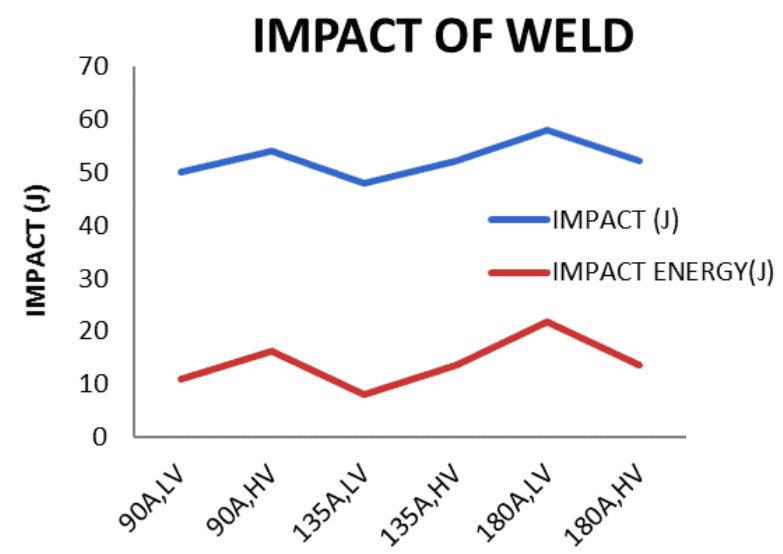

Fig. 5. Graphical representation of impact energy of the weld

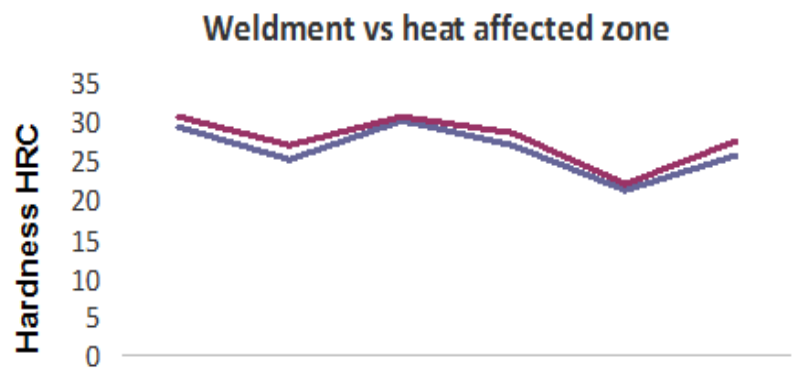

90A, LV 90A, HV 135A, LV 135A,HV 180A, LV 180A, HV

weldment HRC - heat affected zone HRC

Fig. 6. Hardness value weldment and heat affected zone

\section{CORROSION BEHAVIOUR}

The effect of various heat inputs on the corrosion behaviour of shielded metal arc welded mild steel. Thus the as-received sample shows the greatest resistance to corrosion in all the medium, at $180 \mathrm{~A}$, high voltage this is closely followed by sample welded with $180 \mathrm{~A}$,low voltage. The sample welded with $90 \mathrm{~A}$, low voltage which has the least corrosion resistance in all medium during the exposure period studied. Another possible explanation for the above result is that the low heat input welded samples underwent a long period of heating, low heat input could lead to a greater tendency of distortion which may produce a higher weld cracking in the aggressive corrosion medium [10].

\section{CORROSIONRATE}

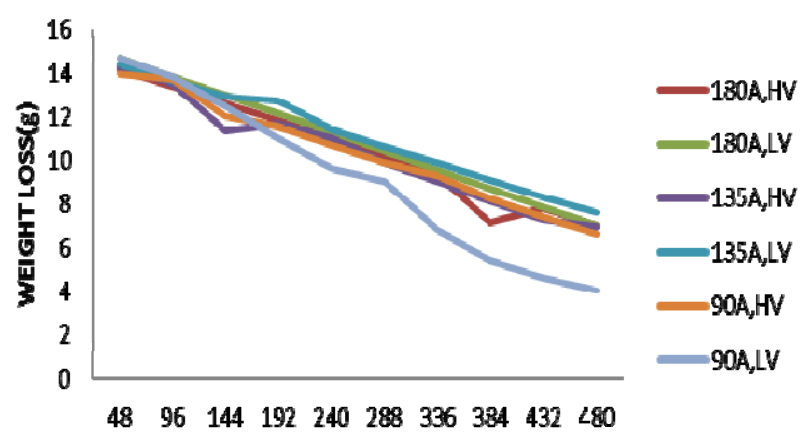

Fig. 7. Graphical representation of weight loss against days
The weld current is the current in the welding circuit during the making of a weld. The higher the current, the higher the power input and the deeper the penetration. However, the use of too high weld current may cause problems such as excessive spatter, electrode overheating and cracking while too high weld voltage could cause the beads to be wider and flatter. The low arc voltage produces a stiffer arc that improves penetration. If the voltage is too low, a very narrow bead will result [11].

\section{CONCLUSION}

The effects of weld process parameter were carried out and the following conclusions are made at the end of the research:

1. The result of this study have shown that welding process parameters have enormous effects on the mechanical, microstructural properties and corrosion behaviours of shielded metal arc welded mild steel in different corrosive medium.

2. An optimum current value of $135 \mathrm{~A}$ is required to be maintained to avoid defects like porosity and weld crater.

3. The corrosion resistivity of the material was more at $135 \mathrm{~A}$, high voltage and this may be due to decrease grain size structure which may have a positive effect on improving local corrosion resistance. corrosion rate was increased in low current and low voltage.

The sample welded with $180 \mathrm{~A}$ and low voltage displayed the highest Rockwell hardness and the same was observed for impact test.

\section{REFERENCES}

[1] Chamberlain, J. ,. (1988). Corrosion for Student of Science and Engineering. London, England.: Longman Scientific and Technology Books.

[2] Fontana, M. (1986). Corrosion Engineering (3rd ed.). New York, NY, USA.: McGraw Hill.

[3] Zhang, G., \& Cheng, Y. (2009). microelectrochemical characterization and MottSchottky analysis of corossion of welded X70 pipeline steel in carbonate/bicarbonate solution. electrochimica acta, 55(1), 316-324.

[4] Wahab, M.A., Nguyen N.T., Demir M. (1997), The effect of geometrical parameters, corrosion and residuals, 15th Australasian Conference on the Mechanics of Structures and Material, (pp. 589-595). Melbourne, Vic.

[5] Adeosun S.O., S. O. (2011). corrosion responses of welded mild steel embedded in coastal soil environment. International conference on innovations in engineering and technology. science and education publishing.

[6] Miller, D. F. (1998). Reviewing and Approving Welding Procedure Specifications. The National Steel Construction Conference Proceedings. new orleans.

[7] Gunaraj, V.,. (1999). Application of response surface methodology for predicting weld bead quality in submerged arc welding of pipes. 
Journal of Material Processing Technology, 88, 266-275.

[8] Olivera Popovic, m. b.-C. (2010). the effect of heat input on the weld metal toughness of surfac welded joint. 14th international research/expert conference "trends in the development of machinery and associated technology", (pp. 6164). mediterranean cruise.

[9] Le May, I. \&. (1986). Metallography and fractography in corrosion related failures. Metallography and corrosion (pp. 119-130.). houston: National Association of Corrosion Engineers,

[10] Llewellyn, D. 1.-B. (1992). Steels Metallurgy and
Application. . Oxford, England: HeinemennButterworths.

[11] J.W.Elmer, J. T. (2002). 6th international conference of trends in welding research, (pp. 15-19). pine mountain.

Authors: Y.O Busari, I.I. Ahmed, Y.L. Shuaib-

Babata, Department of Materials \& Metallurgical Engineering, University of Ilorin, P.M.B. 1515, Ilorin Nigeria +2348034922296

E-mail:busari.oy@unilorin.edu.ng sylbabata@gmail.com shuaib-babata.yl@unilorin.edu.ng 